\title{
Use of toxic bait to manage the south american fruit fly in apple orchards in Southern Brazil
}

\author{
Rafael Borges ${ }^{1}$, Marcos Botton ${ }^{2}$, Mari Inês Carissimi Boff ${ }^{3}$, Cristiano João Arioli ${ }^{4}$, \\ Ruben Machota Junior ${ }^{1}$, Lígia Caroline Bortoli ${ }^{5}$

\begin{abstract}
Anastrepha fraterculus the South American fruit fly, is an important insect pest in apple orchards of southern Brazil, especially in small farms, where it often causes total crop loss. Experiments were conducted to evaluate, during four crop seasons (2009/2010, 2010/2011, 2012/2013, and 2013/2014) in organic and conventional apple orchards in southern Brazil, the toxic bait formulation ANAMED ${ }^{\mathrm{TM}}$ (oils and waxes $49.0 \%+\mathrm{M} 7$ attractant $24.2 \%+$ spinosad insecticide $0.1 \%$ ) for its capacity to reduce the South American fruit fly population. ANAMED applications started after apples with an average diameter of $20 \mathrm{~mm}$ had been thinned, and they were made every 14 days until harvest. ANAMED was sprayed on non-crop vegetation growing on the edges of the orchards at a rate of $1.0 \mathrm{~kg} \cdot \mathrm{ha}^{-1}$. Adult fruit flies were monitored weekly using McPhail traps baited with Torula ${ }^{\mathrm{TM}}$ yeast. Injured fruits were evaluated seven days before harvest. ANAMED reduced the adult population of trapped fruit flies captured in all crop seasons and the injured fruit, except for the first year of evaluation (2009/2010). In conclusion, the sequential use of ANAMED toxic bait over time significantly reduced adult populations of $A$. fraterculus and the percentage of fruits injured by this pest.
\end{abstract} \\ Index terms: Anastrepha fraterculus, Spinosad, Malathion, ANAMED.

\section{Uso de isca tóxica para o manejo da mosca-das-frutas-sul-americana em pomares de maçã no Sul do Brasil}

\section{Corresponding author: rmachota@isca.com \\ Received: February 11, 2021 Accepted: July 30, 2021}

Copyright: All the contents of this journal, except where otherwise noted, is licensed under a Creative Commons Attribution License.

\section{$(\mathrm{cc}) \mathbf{\mathrm { EY }}$}

Resumo - Anastrepha fraterculus a mosca-das-frutas-sul-americana, é uma importante praga em pomares de macieira do Sul do Brasil, principalmente em pequenas propriedades, onde costuma causar perda total da safra. Experimentos foram conduzidos com objetivo de avaliar, por quatro safras (2009/2010, 2010/2011, 2012/2013 e 2013/2014), em pomares de maçã orgânica e convencional, no Sul do Brasil, a formulação de isca tóxica ANAMED ${ }^{\circledR}$ (óleos e ceras 49,0\% + atrativo M7 24,2\% + inseticida spinosad $0,1 \%$ ), quanto à capacidade de reduzir a população da espécie. As aplicações da ANAMED começaram após o raleio, quando as frutas estavam com diâmetro médio de $20 \mathrm{~mm}$, sendo reaplicada a cada 14 dias até à colheita. ANAMED foi pulverizado na vegetação de borda dos pomares a uma taxa de 1,0 kg.ha-1. Moscas-da-frutas foram monitoradas semanalmente, usando armadilhas McPhail iscadas, com levedura Torula ${ }^{\circledR}$. Frutos danificados foram avaliados sete dias antes da colheita. As aplicações de iscas tóxicas ANAMED reduziram a população de adultos de moscas-das-frutas e danos em frutos, em todas as safras, exceto no primeiro ano de avaliação (2009/2010). Em conclusão, o uso sequencial da isca tóxica ANAMED, ao longo do tempo, reduziu significativamente as populações de $A$. fraterculus e a porcentagem de frutos danificados por esta praga.

Termos para indexação: Anastrepha fraterculus, Spinosad, Malathion, ANAMED.

\footnotetext{
${ }^{1}$ Agronomist, PhD, Researcher, ISCA Tecnologies. Ijui-RS, Brazil. E-mail: rborges@isca.com ${ }^{\text {(ORCID 0000-0001-5394-8039) }}$; rmachota@isca.com ${ }^{\text {(ORCID }}$ 0000-0003-3486-0116)

${ }^{2}$ Agronomist, PhD, Researcher. Embrapa Uva e Vinho, Bento Gonçalves-RS, Brazil. E-mail: marcos.botton@embrapa.br (ORCID 0000-0002-0554-3157) ${ }^{3}$ Agronomist, PhD, Professor, Universidade do Estado de Santa Catarina (UDESC-CAV) Lages, SC, Brazil. E-mail: mari.boff@cav.udesc.br (ORCID 0000-0003-1700-8837)

${ }^{4}$ Agronomist, PhD, Professor, Universidade do Estado de Santa Catarina (UDESC-CAV) Lages, SC, Brazil. E-mail: a2micb@cav.udesc.br (ORCID 0000-0003-2012-1726)

${ }^{5}$ Biologist, MSc, Researcher, ISCA Tecnologies. Ijui-RS, Brazil. E-mail: lbortoli@isca.com (ORCID 0000-0002-6336-6881)
} 


\section{Introduction}

The South American fruit fly, Anastrepha fraterculus (Wiedemann) (Diptera: Tephritidae), is one of the main pests in apple orchards in southern Brazil, especially orchards established on small farms, where adults and larvae of the species often cause total crop loss (RIBEIRO, 2010; SANTOS et al., 2017; STUPP et al., 2021). The primary hosts of A. fraterculus belong to the Myrtaceae family (SANTOS et al., 2018; BOLDO et al., 2019) and often grow on the borders of apple or pear orchards, providing an easy route for the pest to infest the crop field. Female flies move into the crop while looking for food and oviposition sites (HICKEL; NORA, 2007; RAMOS et al., 2019), and they begin to attack apples soon after thinning (usually performed in November). These attacks continue until harvest (TEIXEIRA et al., 2011). The management of $A$. fraterculus is based on chemical control, mainly by spraying of organophosphate insecticides ( $\mathrm{SCOZ}$ et al., 2004; EMBRAPA. PIM, 2020), which have been linked to a variety of harmful effects on people as well as on the surrounding ecosystem.

One alternative to reduce the use of these cover sprays is the application of toxic baits combining fruit fly attractants, such as protein or sugarcane molasses, with organophosphate insecticides and water. These baits are placed on the edge of production areas to form a protective barrier between the orchard crop and the surrounding forest, typically the source for $A$. fraterculus infestations (HARTER et al., 2015; NUNES et al., 2020). While this application technique is relatively inexpensive and simple to complete in the field, several studies have shown that these toxic baits are harmful to beneficial insects, such as pollinators, predators, and parasitoids, even when applied only along orchard borders. (GRAVENA, 2004; ZANARDI, 2011; ROSA, 2016).

A toxic bait formulation called ANAMED has been developed for control of fruit fly pests such as $A$. fraterculus. ANAMED contains oleoresins and plant attractants incorporated into the SPLAT (Specialized Pheromone \& Lure Application Technology) emulsion, a technology for controlled release and protection of semiochemicals, phagostimulants, and insecticides. This biologically inert emulsion keeps the active ingredients protected from the harmful effects of environmental factors, such as rain washing and photodegradation, thus enabling the long-lasting release of these compounds (MAFRA-NETO et al., 2013).

ANAMED also contains repellents to some species of beneficial insects, as reported by Zanardi (2011). When mixed with the insecticide spinosad $(0.1 \%$ a.i. $)$, this study found that ANAMED did not have an attractive effect on the fruit fly parasitoid Diachasmimorpha longicaudata (Ashmead) (Hymenoptera: Braconidae). According to Rosa (2016), ANAMED was not attractive to the pollinator, Apis mellifera L. (Hymenoptera: Apidae).

Experiments with toxic baits combining SPLAT and spinosad showed that the attractant and the insecticide were more persistent and maintained high levels of control for longer periods of time compared to other formulations commonly used for fruit fly control, such as malathion (VARGAS et al., 2008, 2010; BORGES, 2011; ZANARDI, 2011). Although results from previous experiments under controlled conditions have shown that ANAMED is effective at controlling $A$. fraterculus (BORGES et al., 2015), no field experiments had been conducted against this species prior to 2009. This work reports the effect of applying ANAMED toxic baits for control of the South American fruit fly, A. fraterculus, in organic and conventional apple orchards of southern Brazil during four crop seasons.

\section{Material and Methods}

Field trials with ANAMED were carried out over three crop seasons (2009-2010, 2010-2011, and 2013-2014) in apple orchards managed under an organic production system and for two crop seasons (2012-2013 and 2013-2014) in apple orchards managed under a conventional production system.

The organic orchard was selected in Linha Bentinho, a municipality of São Joaquim, Santa Catarina State (coordinates: $28^{\circ} 11^{\prime} 13^{\prime \prime} \mathrm{S}$ and $50^{\circ} 03^{\prime} 06^{\prime \prime} \mathrm{W}$; altitude 1,130 $\mathrm{m})$. The orchards have a total experimental area of 3.96 ha divided into two areas of $1.98 \mathrm{ha}$, which were divided into six 0.33 ha plots (approximately 488 plants) that received one of the following treatments: a) ANAMED + spinosad $0.1 \%$, applied at a rate of $1.0 \mathrm{~kg} \cdot \mathrm{ha}^{-1}$ with applications starting in mid-November and continuing until the end of the harvest (first week of February); or b) control, without using any method of control for fruit flies. The apple orchards were composed of mixed cv. 'Gala' and 'Fuji Suprema,' in a 3:1 ratio in alternate rows, grafted onto 'Marubakaido' rootstock. The fruits injured by fruit flies were sampled in cv. 'Gala' plants.

The ANAMED formulation used in these experiments was provided by ISCA Tecnologias Ltda. (Ijuí, RS, Brazil). It is a non-toxic and bio-degradable emulsion containing oils and waxes (49.0\%), hydrolyzed protein and sugars as attractants $(24.2 \%)$. In the study that was conducted in organic apple orchards, ANAMED was combined with the insecticide, spinosad $(0.1 \%$ a.i. $)$ (Tracer $^{\mathrm{TM}}, 480 \mathrm{~g} / \mathrm{L}$, Dow Agrosciences, Indianapolis, IN, USA), while no treatment was applied for $A$. fraterculus in the control treatment.

The toxic baits were applied on spontaneous vegetation on the edges of the orchards using a Stihl ${ }^{\mathrm{TM}}$ BG86C-E portable gas leaf blower, with air displacement volume of $810 \mathrm{~m}^{3} \cdot \mathrm{h}^{-1}$. In the blower tip, a PVC (polyvinyl 
chloride) straight ball valve $(25 \mathrm{~mm})$ was fitted to a trapezoidal plastic tank, with capacity for $3 \mathrm{~kg}$ of toxic bait. To regulate the equipment flow, speed was set at 5 $\mathrm{km} \cdot \mathrm{h}^{-1}\left( \pm 1.4 \mathrm{~m} \cdot \mathrm{s}^{-1}\right)$, and the perimeter to be covered was set as 400 linear meters of edge per ha. The toxic bait flow rate was maintained at $210 \pm 1.0 \mathrm{~g}$ of bait per minute, and $2.5 \mathrm{~g}$ of bait was applied per linear meter on a strip approximately $1 \mathrm{~m}$ wide. This rate was determined by maintaining a 3-m distance between the target plants and the application nozzle. The toxic bait applications started after the fruits had reached a diameter of $20 \mathrm{~mm}$ and ended at harvest time.

The first conventional apple orchards were selected in the municipality of Vacaria, Rio Grande do Sul state. The experiment was carried out in an orchard on São Paulino farm (coordinates: 28 33 '21' 'S and 50 49'34'W; altitude $890 \mathrm{~m}$ ) with an area of 19.14 ha, the trial was conducted during the 2012-2013 crop season. The area was divided into five experimental blocks containing two plots with areas ranging from 2.86 to 4.06 ha. Toxic bait applications started in the ANAMED-treated and control areas on December 12, 2012.

In conventional apple orchards, ANAMED was formulated with the insecticide malathion $(0.8 \%$ a.i.) (malathion, 1,000 g/L, Cheminova A/S, Lemvig, Midtjylland, Denmark). The bait formulation was applied at a rate of $1.0 \mathrm{~kg} . \mathrm{ha}^{-1}$, with reapplications made at the same rate at 14-day intervals, irrespective of data on rainfall volumes $(\mathrm{mm})$, as collected from the Brazilian National Institute of Meteorology - INMET. In the control area, a conventional toxic bait formulated with 5\% hydrolyzed protein and $0.15 \%$ malathion was applied at the same intervals as the treatment applied in the ANAMED area at a rate of $4 \mathrm{~L}$ per ha.

During the experiment, seven spray applications were applied for fruit fly control. Four applications were made for cv. 'Gala' and 'Fuji' using phosmet 150 g.ha ${ }^{-1}$ and fenitrothion $150 \mathrm{~mL}^{-h^{-1}}$ (early November), methidathion $100 \mathrm{~mL}^{\mathrm{h}} \mathrm{ha}^{-1}$ (end of November and early December). For cv. 'Pink Lady ${ }^{\mathrm{TM}}$, three applications of phosmet $150 \mathrm{~g}^{\text {g.ha }}{ }^{-1}$ (mid-January) and two applications of methidathion 150 $\mathrm{mL} \cdot \mathrm{ha}^{-1}$ (end of March) were performed. The fruits injured by fruit flies were sampled in plants of three cultivars, 'Gala,' 'Fuji,' and 'Pink Lady' at the end of February, the end of March, and in early May, respectively.

In the 2013-2014 crop season, the experiment was carried out in the vineyard Pericó, São Joaquim, SC (coordinates: $28^{\circ} 09^{\prime} 36^{\prime \prime} \mathrm{S}$ and $49^{\circ} 45^{\prime} 15^{\prime \prime} \mathrm{W}$; altitude $1,180 \mathrm{~m}$ ), over a total area of 73.8 ha in orchards with 'Maxi Gala' and 'Fuji Suprema' apple cultivars under conventional management, planted in alternating rows in a 2:3 ratio. The area was divided into nine experimental blocks, each containing two plots, with total areas ranging from 4.53 to 3.63 ha. During the experiment, in the areas treated with ANAMED + malathion $(0.8 \%$ a.i. $)$ and with control (conventional toxic bait formulated with $5 \%$ hydrolyzed protein + malathion $0.15 \%$ ), three spray applications were used to manage fruit flies, namely, fenitrothion $150 \mathrm{~mL} \cdot \mathrm{ha}^{-1}$ (end of October), methidathion $100 \mathrm{~mL} \cdot \mathrm{ha}^{-1}$ (end of November) and malathion $100 \mathrm{~mL} \cdot \mathrm{ha}^{-1}$ (end of December). Fruits injured by fruit flies were sampled in cv. 'Fuji Suprema' plants at the end of March.

Evaluated parameters - During the four crop seasons that corresponded to the duration of these experiments, Isca Bola ${ }^{\mathrm{TM}} \mathrm{McPhail}$ traps were installed in the first row of apple trees along the forest border of each plot, hung on trees at a height of $1.8 \mathrm{~m}$ from the ground. The traps were spaced $25 \mathrm{~m}$ apart. Data on fluctuations in A. fraterculus populations at the trial sites were collected through weekly monitoring, using Isca Bola McPhail traps baited with Torula yeast (Isca Tecnologias Ltda., Ijuí, RS), at a rate of six tablets of $3 \mathrm{~g}$ of yeast per $\mathrm{L}$ of water; $500 \mathrm{~mL}$ of this attractant solution was used per trap. For each monitoring session, a $5 \%$ sample of the total number of captured fruit flies was collected for subsequent identification of the species according to the identification keys of Zucchi (2000). The number of captured insects was expressed by the FTD index (flies/trap/day). The attractive food source in the traps was replaced every 15 days as recommended by the manufacturer.

The percentage of fruits injured by $A$. fraterculus was determined by sampling fruits collected in previously labelled plants (four per plot) from the main apple varieties in the area. Two plants were selected for sampling for each trap located along the forest edge at $15 \mathrm{~m}$ from the trap in either direction. Seven days before the beginning of harvest, 50 fruits per plant were collected for a total of 200 fruits per plot $(n=200)$. The fruits were evaluated for the presence of external damage (punctures) and cut crosswise to evaluate the presence of damage by oviposition and/or presence of larvae. Damage severity was not evaluated as it was assumed that any external damage observable by the naked eye hinders the suitability of the fruit for fresh consumption.

Statistical analysis - These experiments were conducted in a randomized block design. Each trap installed in the orchard and each sampled plant was considered to be a replicate. The data underwent nonparametric analysis of variance using the Kruskal-Wallis test. The Student-Newman-Keuls test for multiple comparisons was used for analysis of adult monitoring data, while the Mann-Whitney test was used for injured fruits. Both tests used a significance level of 5\% through the software BioEstat 5.0 (AYRES et al., 2007). 


\section{Results and Discussion}

Owing to the similarity in crop type and infestation rate among trial sites, species identification was performed only in the organic orchard and extrapolated to the rest of the trial area. A total of 110 adult fruit flies were captured in monitoring traps placed at the trial site established in the organic orchard. These flies were identified to species, and $93 \%$ of them were found to belong to the species $A$.

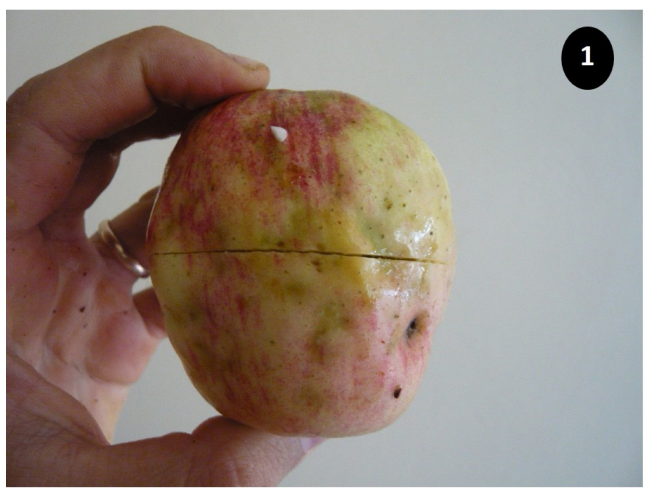

fraterculus. Similar data were reported by Ribeiro (2010) and Hickel and Nora (2007) for fruit fly populations in the region of Planalto Catarinense (SC), Brazil, a geographic region close to the areas used in the present study. Given the dominance of $A$. fraterculus flies in these trap captures, fruit damage detected in the trial areas was assumed to have been largely inflicted by this species. Further supporting this assumption, damage found in sampled fruits was very characteristic of $A$. fraterculus attacks (Figure 1), although larvae did not survive in the fruit.

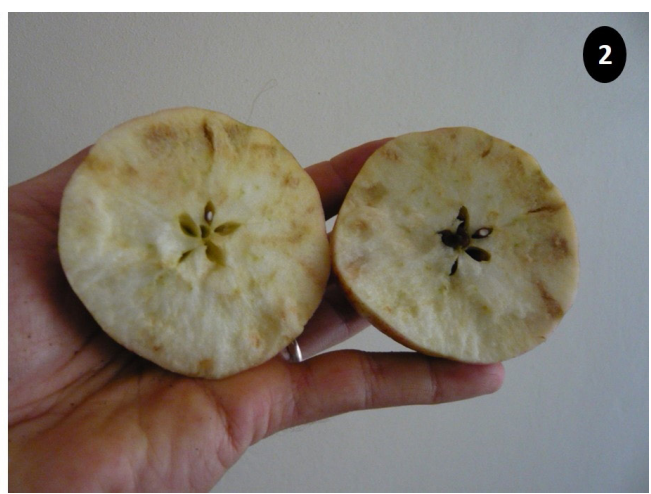

Figure 1. Damage by Anastrepha fraterculus in apple fruits: 1 - external deformation; 2 - cork spots in the pulp.

Organic orchards - In the 2009/2010 crop season, applications of ANAMED reduced the total number of flies caught in the traps by $74.2 \%$ compared to the control. The population in the control area reached a peak on January
15, 2010, with a mean of 2.0 FTD (Figure 2), and the values remained above $0.5 \mathrm{FTD}$ - the economic threshold as determined by IAP (Integrated Apple Production, from the Portuguese 'PIM - Produção Integrada de Maçãs') until harvest $(01 / 29 / 2010)$.

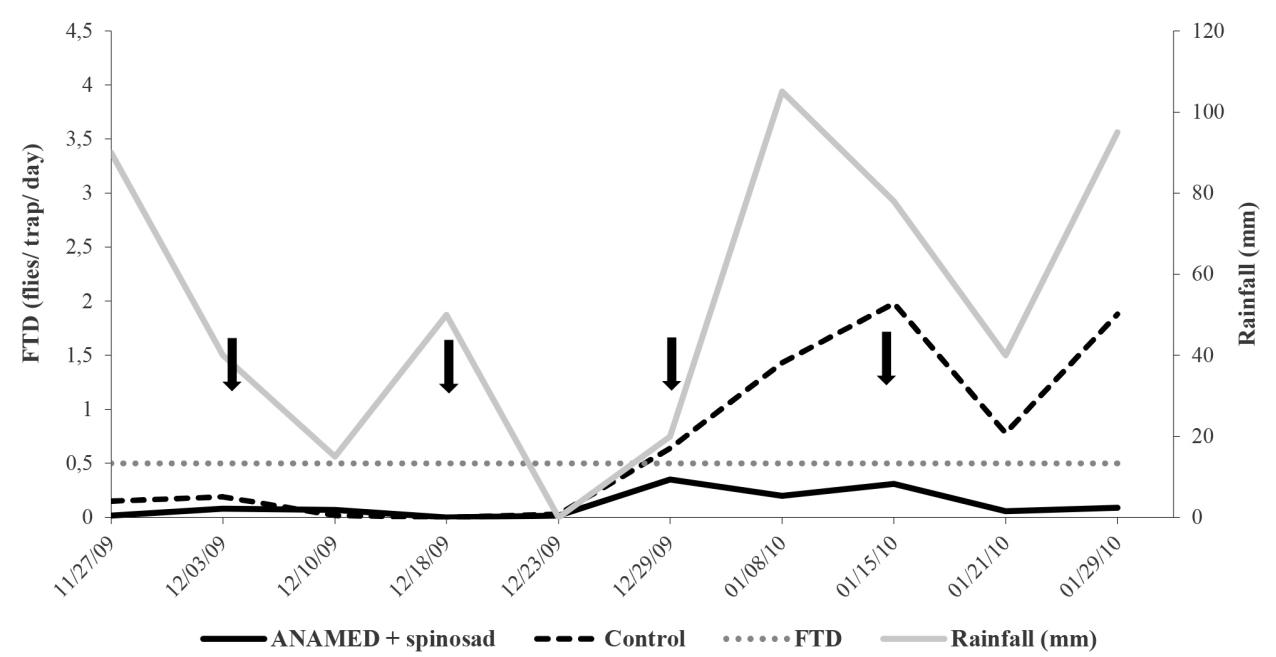

Figure 2. Daily means of Anastrepha fraterculus adults trapped (FTD) in the areas under ANAMED application and control areas (no insecticide applications) during the 2009/2010 crop season in an organic apple orchard (cv. 'Gala'). São Joaquim-SC, Brazil. Note: The black arrows indicate the dates of ANAMED toxic bait application.

In the 2010/2011 crop season, the first treatment application was delayed, leading to a population peak of A. fraterculus at the beginning of the evaluation period (December 2, 2010) (Figure 3). However, ANAMED treatments reduced the number of fruit flies captured in the traps by $66.2 \%$ toward the latter end of the $2010 / 2011$ crop season, helping to reduce fruit damage compared to the control (Table 1). Similar data were reported by Thomas and Mangan (2005) with reductions of captures of Mexican fruit fly Anastrepha ludens (Loew) (Diptera: Tephritidae) by $47-63 \%$ in citrus orchards treated with GF-120NF toxic bait during two crop seasons in Texas, 
USA. The efficiency of the same bait formulation in reducing populations of apple maggot, Rhagoletis pomonela (Walsh) (Diptera: Tephritidae), was reported by
Pelz et al. (2005) and Yee (2007). GF-120NF applications reduced infestations in apple orchards in the states of Michigan and Washington, USA, respectively.

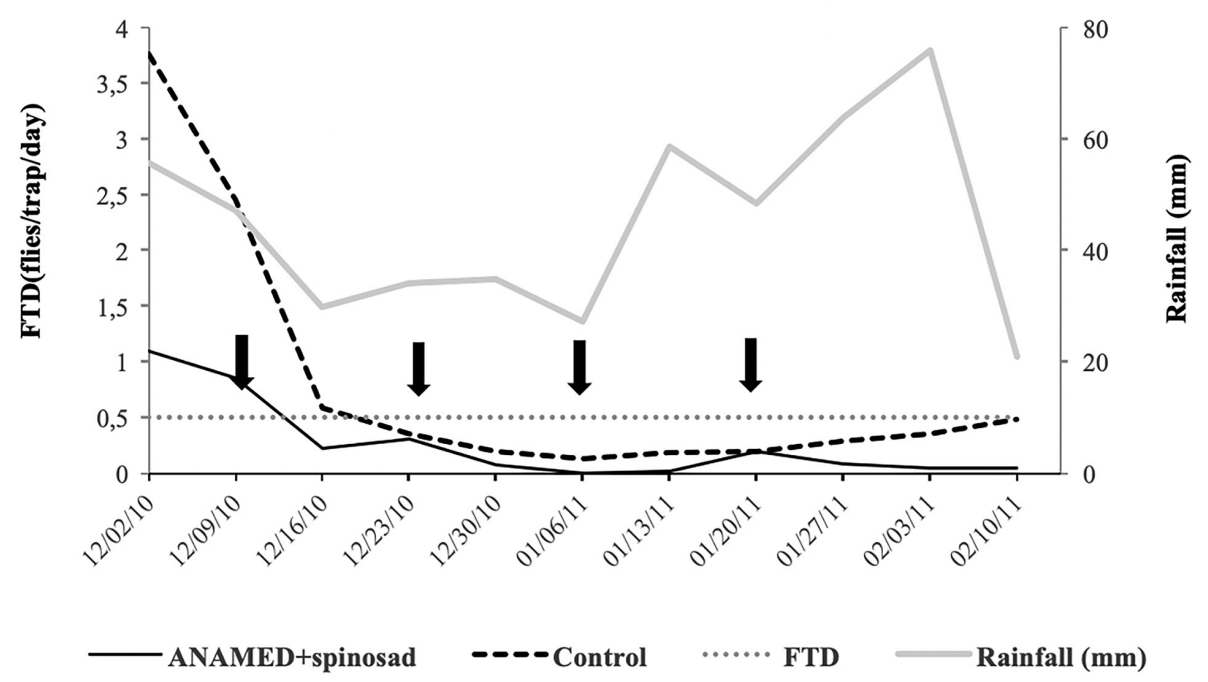

Figure 3. Daily means of Anastrepha fraterculus adults trapped (FTD) in the areas under ANAMED toxic bait application and control (no insecticide applications) during the 2010/2011 crop season in an organic apple orchard cv. 'Gala.' Sao Joaquim, SC, Brazil. Note: The black arrows indicate the dates of application of the ANAMED toxic bait.

Table 1. Mean number $( \pm \mathrm{SD})$ and percentage of apple cv. 'Gala' fruits with internal and external damage caused by Anastrepha fraterculus in organic orchards treated with ANAMED toxic bait applications and control (no insecticide applications) in the 2009/2010, 2010/2011 and 2013/2014 crop seasons. São Joaquim, SC, Brazil.

\begin{tabular}{|c|c|c|c|}
\hline & \multicolumn{3}{|c|}{ Crop season } \\
\hline & $2009 / 2010$ & $2010 / 2011$ & $2013 / 2014$ \\
\hline Treatments & \multicolumn{3}{|c|}{ - - - Mean number $( \pm \mathrm{SD})^{1}$ and $\%$ of injured fruits - - - - } \\
\hline ANAMED + spinosad $0.1 \%$ & $9.1( \pm 7.02) \mathrm{a}^{*} 18 \%$ & $40( \pm 5.35)$ a $80 \%$ & $7.2( \pm 1.30)$ a $15 \%$ \\
\hline Control & $15.5( \pm 9.00)$ a $31 \%$ & $48( \pm 1.43)$ b $97 \%$ & $45( \pm 2.74)$ b $90 \%$ \\
\hline
\end{tabular}

Note: ${ }^{1}$ Mean number, considering four replicates of 50 fruits $(n=200)$ per treatment.

* Mean numbers followed by the same letter do not differ statistically by the Mann-Whitney test $(\mathrm{p}<0.05)$.

In the 2013/2014 crop season, the authors sought to address the timing problems that occurred in the 2010/2011 season by beginning application of ANAMED in early November. The highest population peaks in this second season of the trial were found in the control area, reaching 3.8 FTD in mid-January compared to $2.0 \mathrm{FTD}$ in the area under ANAMED treatment in the same period (Figure 4). Although the applications of ANAMED were not efficient in maintaining the population level below 0.5 FTD (economic threshold for this pest), they reduced the total number of flies caught in the traps by $40 \%$ compared to the control treatment. 


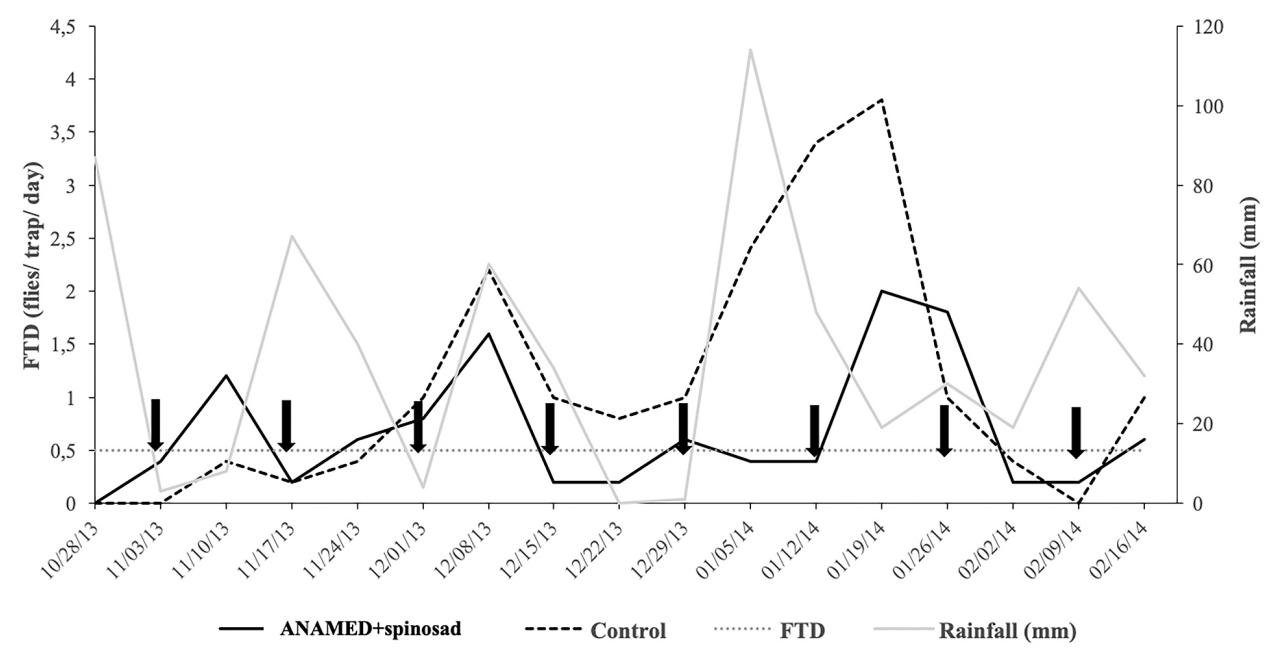

Figure 4. Daily means of Anastrepha fraterculus adults trapped (FTD) in the areas under ANAMED toxic bait application and control (no insecticide applications) during the 2013/2014 crop season in an organic apple orchard cv. 'Gala.' Sao Joaquim, SC, Brazil.Note: The black arrows indicate the dates of the ANAMED toxic bait application.

In the $2010 / 2011$ crop season, A. fraterculus populations in the trial area were relatively high. The treatment with ANAMED reduced these populations to below the economic threshold in apple orchards in Southern Brazil (0.5 FTD) (KOVALESKI; RIBEIRO, 2003) within one week, and maintained them below that threshold for the rest of the season. This result indicates a trend of progressive increase in the control of adults by ANAMED and an increase of the effectiveness of this toxic bait when the product is reapplied on the edges of the treated area (Figure 3). A hypothesis for this behavior is that insects were attracted to the edges of the plot after the toxic bait applications had started, leading to a reduction of fruit fly populations neighboring the areas under treatment.

In the 2009/2010 crop season, fruit damage in plots treated with ANAMED (Table 1) was reduced by $12.7 \%$ compared to control plots, but this difference was not significant $(\mathrm{p}<0.87)$. Although a threshold of 0.5 FTD was not reached in the area treated during the 2009/2010 crop season, the rate of fruit damage was found to be around $18 \%$ (Table 1) in plots treated with ANAMED. This level of damage did not differ from the level found in the control area. In contrast, $A$. fraterculus populations captured in monitoring traps in the control plots exceeded economic threshold values on five sampling dates (Figure 2). A similar fact was reported by Nunes et al. (2020), in apple orchards with 1.6 hectares in length, in which the bait-toxic Gelsura (Basf S/A) was applied.

These results indicate that, for small apple orchards (up to $3 \mathrm{ha}$ ), the established economic threshold of 0.5 FTD may not be set low enough to reflect the potential of the monitored population to cause significant damage to the crop. This suggests the need for adjustments (e.g., a cumulative level between evaluations as advocated by the IAP). This may explain why the initial focus of this pest within the orchard area is the edge; after that, it subsequently expands to the center (RAMOS et al., 2019), in small areas, where a proportion of the edge is much higher, small increases in the population, concentrated at the edges, compromise expressive volumes of fruits. Anther fact is that the first impulse of mated female fruit flies is to search for oviposition places after they have reached the orchards (KOVALESKI et al., 2000). This behavior was previously reported by Pelz et al. (2005) in apple and blueberry (Vaccinium myrtillus L.) orchards sprayed with GF-120NF to control $R$. pomonella and blueberry maggot Rhagoletis mendax Curran (Diptera: Tephritidae). This finding suggests that a portion of the fruit fly population was not attracted by the ANAMED toxic bait but by the fruits and the attractant and yellow color of the monitoring trap set.

In the second year of evaluation (2010/11 season), applications of ANAMED in the orchards significantly decreased the number of trapped adults, reducing the number of injured fruits by $16.9 \%$. However, the most remarkable result was found in the third year of evaluation (2013/2014 season), when applications of ANAMED in the organic orchards resulted in a $75 \%$ reduction in the number of injured fruits (Table 1).

One hypothesis to explain these variations in levels of damage, especially in the control areas, is the great capability of $A$. fraterculus females to cause yield losses. Barros et al. (1983) reported that there is a 70\% likelihood that females will make punctures when they find an apple fruit. Also, Sugayama et al. (1997) reported that one $A$. fraterculus female can cause great damage because it can easily find apple fruits among branches and leaves and, within 5 minutes, it can make up to seven punctures. 
Therefore, even a small population of $A$. fraterculus can induce a disproportionately high level of crop damage.

Conventional orchards - In the 2012/2013 harvest, applications of ANAMED toxic bait combined with malathion, an organophosphate insecticide, reduced the total number of trapped flies by $19 \%$ compared to the control in an apple orchard managed under a conventional system, in which seven spray applications were performed for fruit fly control. In the period that toxic baits were applied in the area (12/06/2012 to 03/07/2013), there were six population peaks exceeding 0.5 FTD in the control area, while there were only two such peaks in the area treated with applications of ANAMED (Figure 5).

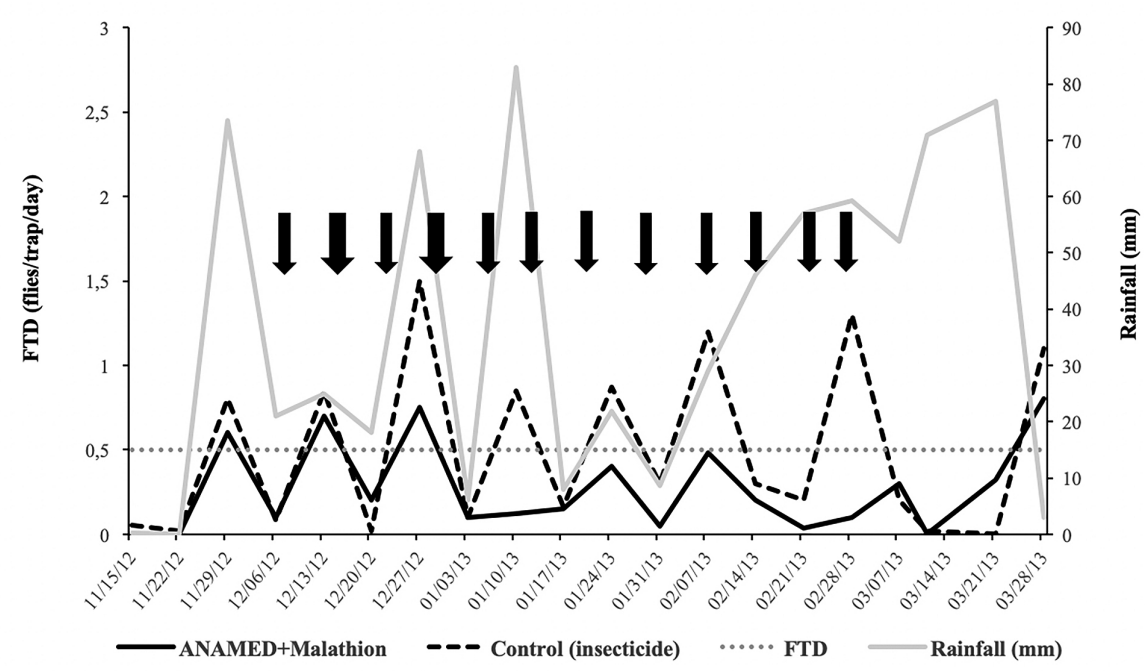

Figure 5. Daily means of Anastrepha fraterculus adults trapped (FTD) in the areas under ANAMED toxic bait application and control (conventional management with organophosphate insecticide applications) during the 2012/2013 crop season in a conventional apple orchard cvs. 'Gala,' 'Fuji,' and 'Pink Lady.' Vacaria, RS, Brazil. Note: The black arrows indicate the dates of application of the ANAMED toxic bait.

In the 2013/2014 season, applications of the ANAMED toxic bait combined with malathion reduced the total number of trapped flies by $36.7 \%$ compared to control in an apple orchard managed under a conventional system in which three spray applications were used for fruit fly control. There were population peaks above the control level (0.5 FTD) within one month (from the end of December 2013 to January 2014) for both evaluated treatments. However, the area treated with ANAMED presented lower population peaks compared to the control area (Figure 6).

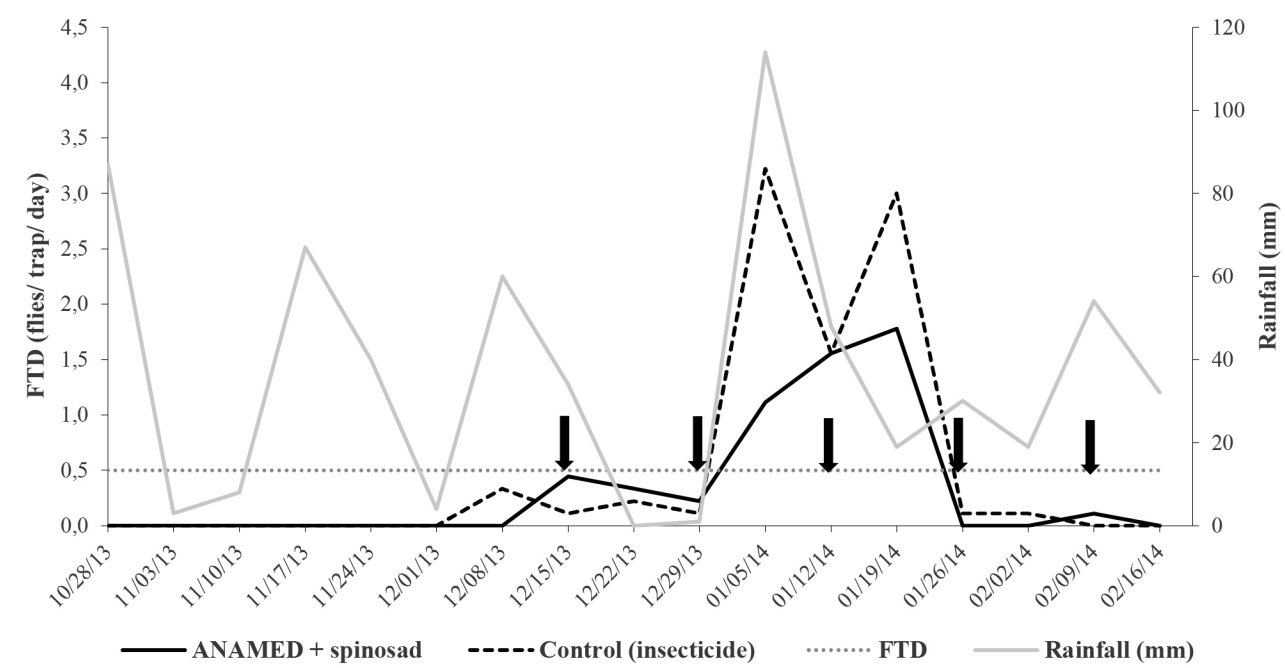

Figure 6. Daily means of Anastrepha fraterculus adults trapped (FTD) in the areas under ANAMED toxic bait application and control (conventional management with organophosphate insecticide applications) during the 2013/2014 crop season in a conventional apple orchard cv. 'Fuji Suprema.' Sao Joaquim, SC, Brazil. Note: The black arrows indicate the dates of application of the ANAMED toxic bait. 
The effect of ANAMED applications on $A$. fraterculus populations was a significant reduction in fruit damage in two ('Fuji' and 'Pink Lady') out of the three cultivars evaluated during the 2012/2013 season in conventional apple orchards (Figure 7). Thus, the decrease in the percentage of fruits injured by fruit flies throughout the crop season reinforces the importance of sequential toxic bait applications.

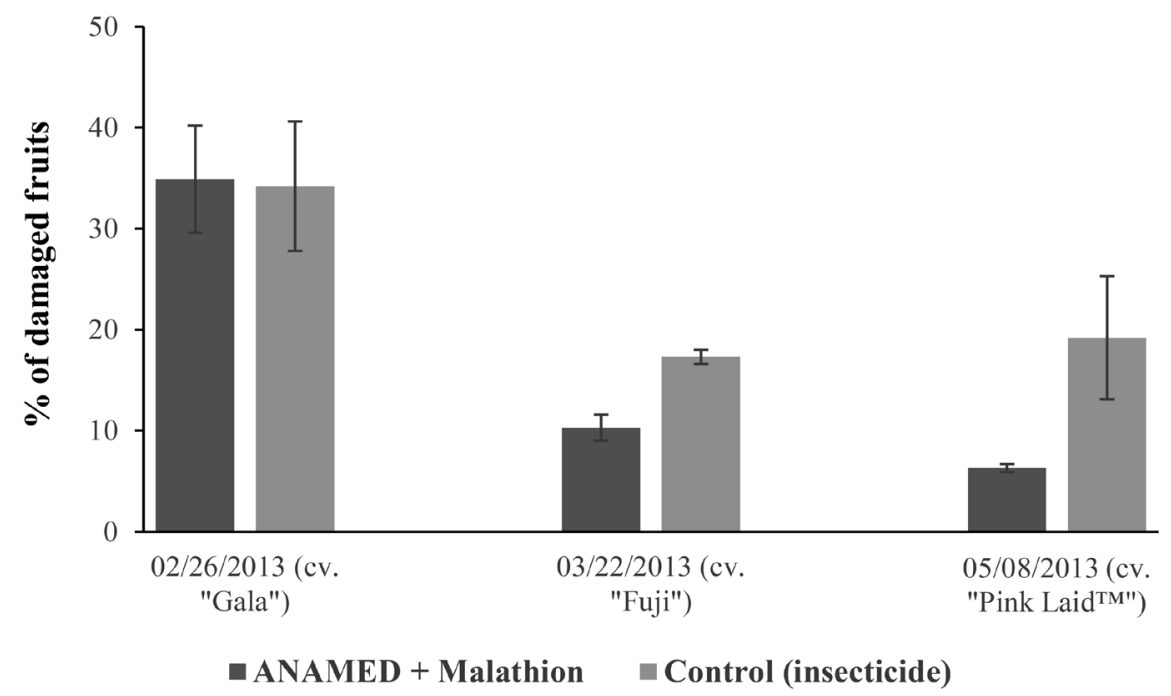

Figure 7. Percentage $( \pm \mathrm{SD})$ of cvs. 'Gala,' 'Fuji,' and 'Pink Lady' fruits with internal and external damage caused by Anastrepha fraterculus from conventional orchards treated with ANAMED toxic bait and control (management with organophosphate insecticide applications) in the 2012/2013 crop season. Vacaria, RS, Brazil. Note: ns = Mean numbers do not differ statistically by the Mann-Whitney test $(\mathrm{p}<0.05)$.

The results found in the conventional apple (cv. 'Fuji Suprema') orchard during the 2013/2014 season showed that the rate of crop damage did not differ significantly $(\mathrm{p}$ $<0.87$ ) between plots treated with ANAMED and those under conventional control practices (Table 2).

Table 2. Mean number $( \pm \mathrm{SD})$ and percentage of apple cv. 'Fuji Suprema' fruits with internal and external damage caused by Anastrepha fraterculus in conventional orchards treated with ANAMED toxic bait and control (management with organophosphate insecticide applications) in the 2013/2014 crop season. São Joaquim, SC, Brazil.

\begin{tabular}{cc}
\hline - - - - Mean number $( \pm \mathrm{SD})$ and $\%$ of injured fruits - - - \\
\hline ANAMED + spinosad $0.1 \%$ & Control (insecticide) \\
$0.5( \pm 0.50)$ a $1 \%$ & $3.3( \pm 2.58)$ a $7 \%$ \\
\hline
\end{tabular}

Note: Mean numbers followed by the same letter do not differ statistically by the Mann-Whitney test $(\mathrm{p}<0.05)$.

The results for fruit damage indicate that the use of ANAMED on the edges of small orchards under an organic and/or conventional production system cannot be recommended as the only management strategy to control A. fraterculus. Under such conditions, the use of toxic bait applications is advisable as a strategy within an Integrated Pest Management (IPM) program. The proposal for integrated control has been passed on by researchers and official research institutions (KOVALESKI; RIBEIRO, 2003; RIBEIRO, 2010) to producers, suggesting that they should adopt other practices, such as population control in primary hosts, spray cover applications for conventional areas, and release of parasitoids (ZALUCKI et al., 2009).
Thus, it should be stressed that natural enemies can be used in combination with ANAMED applications because the evaluations of the effects of this toxic bait formulation with spinosad on the fruit fly parasitoid Diachasmimorpha longicaudata (Ashmead) (Hymenoptera: Braconidae) have shown that the formulation is not harmful to this natural enemy (ZANARDI, 2011).

Tests with applications of GF-120NF for the oriental fruit fly Bactrocera dorsalis (Hendel) (Diptera: Tephritidae) in melon Cucumis melo L., conducted by Prokopy et al. (2004), showed that application on the border was not effective in preventing crop damage. When females reared in a laboratory were released along the edge 
of a melon crop with a strip of toxic bait between them and the culture, only $5.4 \%$ of the released females were found dead near the edge while $17 \%$ were found dead within the crop. The authors suggested that the late mortality effect of spinosad is a factor that should be taken into account. Yee and Chapman (2005) found that GF-120NF was toxic to females of the Western cherry fruit fly Rhagoletis indifferens Curran (Diptera: Tephritidae). However, GF$120 \mathrm{NF}$ did not prevent the fertilized females from laying eggs on fruits. The authors related this fact to the lowerimpact effect of the spinosad formulation compared to toxic baits using organophosphate insecticides.

Applications of ANAMED in organic apple orchards using spinosad significantly reduced the population of trapped A. fraterculus adults. However, given the levels of damage found on the assessed fruits, new strategies need to be sought for toxic bait application, especially in small orchards such as those used in the present study. Options include direct and continuous treatment of primary host plants neighboring the orchard to prevent migration of the pest into the cultivated crop; increases in the rate of toxic bait to be applied and/or reduction of reapplication intervals; and applications in broader swaths on the edges of the crop field, as suggested by Prokopy et al. (2004). These strategies should be explored in future research.

\section{Conclusions}

ANAMED toxic bait $\left(1.0 \mathrm{~kg} \cdot \mathrm{ha}^{-1}\right)$ applied on the edges of organic and conventional apple orchards (biweekly reapplications) reduces infestations of $A$. fraterculus adults.

ANAMED applications were not able to prevent the access of $A$. fraterculus adults inside the production areas.

ANAMED applications reduce fruit damage caused by $A$. fraterculus.

\section{References}

AYRES, M.; AYRES JÚNIOR, M.; AYRES, D.L.; SANTOS, A. BioEstat 5.0: aplicações estatísticas nas áreas das ciências biológicas e médicas. Belém: Sociedade Civil Mamirauá, 2007. 364 p.

BARROS, M.D.; NOVAES, M.; MALAVASI, A. Estudo do comportamento de oviposição em Anastrepha fraterculus (Wiedemann, 1830) (Diptera: Tephritidae), em condições naturais e de laboratório. Anais da Sociedade Entomológica do Brasil, Londrina, v.12, p.243-247, 1983.
BOLDO, R. S.; KOVALESKI, A.; ROSA, J. M.; BOFF, M. I. C.; FRANCO, C. R. Development of Anastrepha fraterculus (Wiedemann, 1830) (Diptera: Tephritidae) in different host fruits. Journal of Agricultural Science, Cambridge, v.11, n.8, 2019.

BORGES, R. Seleção e avaliação de novas formulações de iscas tóxicas para o manejo de Anastrepha fraterculus em pomares de macieira. 2011. $76 \mathrm{f}$. Dissertação (Master's in Plant Production) - Centro de Ciências Agroveterinárias, Universidade do Estado de Santa Catarina, Lages, 2011.

BORGES, R.; MACHOTA JUNIOR, R.; BOFF, M. I. C.; BOTTON, M. Efeito de iscas tóxicas sobre Anastrepha fraterculus (Wiedemann) (Diptera: Tephritidae). BioAssay, Piracicaba, v.10, p.1-8, 2015.

EMBRAPA. PIM - Produção Integrada de Maçã: normas para solicitação de inclusão de agrotóxicos e agroquímicos na grade de produção - safra 2021/2022. Bento Gonçalves: Embrapa Uva e Vinho, 2020. Disponível em: https:/www.embrapa.br/uva-e-vinho/ busca-de-publicacoes/-/publicacao/1124155/pim--producao-integrada-de-maca-normas-para-solicitacao-deinclusao-de-agrotoxicos-e-agroquimicos-na-grade-deproducao-safra-20212022. Acesso em: 06 ago. 2020.

GRAVENA, S. Perspectiva de emprego de tratamentos fitossanitários para incremento da exportação de citros. Laranja, Cordeirópolis, v.25, p.389-411, 2004.

HARTER, W.R.; BOTTON, M.; NAVA, D.E.; GRUTZMACHER, A.D.; DA SILVA GONÇALVES, R.; JUNIOR, R.M.; ZANARDI, O.Z. Toxicities and residual effects of toxic baits containing spinosad or malathion to control the adult Anastrepha fraterculus (Diptera: Tephritidae). Florida Entomologist, Gainesville, v.98, n.1, p.202-208, 2015.

HICKEL, E.R.; NORA, I. Moscas de asas maculadas capturadas em frascos caça-mosca na região do Vale do Rio do Peixe. Agropecuária Catarinense, Florianópolis, v.20, p.47-50, 2007.

KOVALESKI, A.; RIBEIRO, L.G. Manejo de pragas na produção integrada de maçã. p.61-76. In: PROTAS, J. F. S.; SANHUEZA, R. M. V. Produção integrada de frutas: o caso da maçã no Brasil. Bento Gonçalves: Embrapa Uva e Vinho, 2003. 90 p. 
KOVALESKI, A.; SUGAYAMA, R.L.; URAMOTO, K.; MALAVASI. A. Moscas-das-frutas nos Estados Brasileiros: Rio Grande do Sul. p. 285-290. In: MALAVASI, A.; ZUCCHI, R. A. Moscas-das-frutas de importância econômica no Brasil: conhecimento básico e aplicado. Ribeirão Preto: Holos Editora, 2000.327 p.

MAFRA-NETO, A.; DE LAME, F. M.; FETTIG, C. J.; MUNSON, A. S.; PERRING; T. M.; STELINSKI, L. L; STOLTMAN, L. L; MAFRA, L. E. J.; BORGES, R.; VARGAS, R. I. Manipulation of insect behavior with specialized pheromone and lure application technology (SPLAT ${ }^{\circledR}$ ). In: KOIVUNEN, M.; DUKEM S.O.; COATS, J.C.; BECK, J.J. Pest Management with natural products. Albany: American Chemical Society, 2012. p.31-58.

NUNES, M.Z.; BARONIO, C.A.; SCHUTZE, I.X.; BERNARDI, D.; ARIOLI, C.J.; JUNIOR, R.M.; BOTTON, M. Toxicity of baits and their effects on population suppression of Anastrepha fraterculus (Diptera: Tephritidae): implications for field management. Environmental Entomology, College Park, v.49, n.3, p.638-644, 2020.

PELZ, K.S.S; ISAACS, R.; WISE, J.C.; GUT, L.J. Protection of fruit against infestation by Apple Maggot and Blueberry Maggot (Diptera: Tephritidae) using compounds containing Spinosad. Journal of Economic Entomology, Lanham, v.98, n.2, p.432-437, 2005.

PROKOPY, R.J.; MILLER, N.W.; PIÑERO, J.C.; ORIDE, L.; CHANEY, N.; REVIS, H.; VARGAS; R. I. How effective is GF-120 fruit fly bait spray applied to border area sorghum plants for control of melon flies (Diptera: Tephritidae)? Florida Entomologist, Gainesville, v.87, n.3, p.354-360, 2004.

RAMOS, Y.J.; COSTA, T.L.; SANTOS, A.A.; DA SILVA, R.S.; DA SILVA GALDINO, T.V.; PICANÇO, M.C. Geostatistical analysis as essential information for efficient decision making in Anastrepha fraterculus (Diptera: Tephritidae) control in apple orchards. Crop Protection, Amsterdam, v.120, p.50-57, 2019.

RIBEIRO, L.G. Manejo das principais pragas da macieira no Brasil. Agropecuária Catarinense, Florianópolis, v. 23, p. 149-157, 2010.
ROSA, J. M. Diagnóstico dos serviços de polinização em pomares de macieira e efeito de formulações de iscas tóxicas sobre Apis mellifera Linnaeus, 1758 (Hymenoptera: Apidae) em laboratório e campo. 2016. 109 f. Tese (Doctorate Crop Protection Graduate Program) - Universidade Federal de Pelotas, Pelotas, 2016.

SANTOS, J.P.D.; REDAELLI, L.R.; SANT'ANA, J.; HICKEL, E.R. Population fluctuation and estimate of generations number of Anastrepha fraterculus (Diptera: Tephritidae) in apple orchard in Caçador, Santa Catarina, Brazil. Arquivos do Instituto Biológico, São Paulo, v.84, 2017.

SANTOS, J.P.; DE LACERDA, A.E.B.; ALVES, A.C.; ANSILIERO, A.A. Índices de infestação da mosca-dasfrutas sul-americana em frutíferas nativas em Caçador, SC, Brasil. In: CONGRESSO LUSO-BRASILEIRO DE HORTICULTURA (CLBHort), 1. 2018, Lisboa. Anais [...]. Lisboa: Associação Portuguesa de Horticultura, 2018 .

SCOZ, P.L.; BOTTON, M.; GARCIA, M.S. Controle químico de Anastrepha fraterculus (Wid.) (Diptera: Tephritidae). Ciência Rural, Santa Maria, v.34, n.6, p.1689-1694, 2004.

STUPP, P.; JUNIOR, R.M.; CARDOSO, T.D.N.; PADILHA, A.C.; HOFFER, A.; BERNARDI, D.; BOTTON, M. Mass trapping is a viable alternative to insecticides for management of Anastrepha fraterculus (Diptera: Tephritidae) in apple orchards in Brazil. Crop Protection, Amsterdam, v.139, p.105391, 2021

SUGAYAMA, R.L.; BRANCO, E.S.; MALAVASI, A.; KOVALESKI, A.; NORA, I. Oviposition behavior and preference of Anastrepha fraterculus in apple and dial pattern of activity in an apple orchard in Brazil. Entomologia Experimentalis et Applicata, Amsterdam, v.83, p.239-245, 1997.

TEIXEIRA, R.; AMARANTE, C.V.T.; BOFF, M.I.C.; RIBEIRO, L.G. Controle de pragas e doenças, maturação e qualidade de maçãs 'Imperial Gala' submetidas ao ensacamento. Revista Brasileira de Fruticultura, Jaboticabal, v.33, n.2, p.394-401, 2011.

THOMAS, D.B.; MANGAN, R.L. Nontarget impact of spinosad GF-120 bait sprays for control of the Mexican fruit fly (Diptera: Tephritidae) in Texas citrus. Journal of Economic Entomology, Lanham, v.98, n.6, p.19501956, 2005. 
VARGAS, R.I.; PIÑERO, J.C.; JANG, E.B.; MAU, R.F.L.; STARK, J.D.; GOMEZ, L.; STOLTMAN, L.; MAFRA-NETO, A. Response of Melon Fly (Diptera: Tephritidae) to weathered SPLAT-Spinosad-Cue-Lure. Journal of Economic Entomology, Lanham, v.103, n.5, p.1594-1602, 2010.

VARGAS, R.I.; STARK, J.D.; HERTLEIN, M.; MAFRANETO, A.; COLER, R.; PIÑERO J.C. Evaluation of SPLAT with spinosad and methyl eugenol or cue-lure for "attract-and-kill" of oriental and melon fruit flies (Diptera: Tephritidae) in Hawaii. Journal of Economic Entomology, Lanham, v.101, p.750 -768, 2008.

YEE, W.L. Attraction, feeding, and control of Rhagoletis pomonella (Diptera: Tephritidae) with GF-120 and added ammonia in Washington State. Florida Entomologist, Lutz, v.90, n.4, p.665-673, 2007.

YEE, W.L.; CHAPMAN, P.S. Effects of GF-120 concentrations on attraction, feeding, mortality, and control of Rhagoletis indifferens (Diptera: Tephritidae). Journal of Economic Entomology, Lanham, v.98, p.1654 $-1663,2005$.
ZALUCKI, M.P.; ADAMSON, D.; FURLONG, M.J. The future of IPM: whither or wither? Australian Journal of Entomology, Victoria, v.48, n.2, p.85-96, 2009.

ZANARDI, O. Z. Biologia de Ceratitis capitata (Widemann, 1824) (Diptera: Tephritidae) em caquizeiro, macieira e videira e avaliação de iscas tóxicas para o seu controle e sobre o parasitoide Diachasmimorpha longicaudata (Ashmead, 1905) (Hymenoptera: Braconidae). 2011. 86f. Dissertation (Master's in Crop Protection) - Universidade Federal de Pelotas, Pelotas, 2011.

ZUCCHI, R. A. Taxonomia. In: MALAVASI, A.; ZUCCHI, R. A. Moscas-das-frutas de importância econômica no Brasil: conhecimento básico e aplicado. Ribeirão Preto: Holos Editora, 2000. 327 p. 